\title{
Effects of working years in cold environment on the musculoskeletal system and carpal tunnel symptoms
}

\author{
Soğuk ortamda çalışma yıllarının kas iskelet sistemi ve karpal tünel sendromu \\ semptomları üzerine etkisi
}

(1) Yasin Devran ALTUNTAŞ, ㄴ) Tamer ÇANKAYA

\begin{abstract}
Summary
Objectives: Musculoskeletal disorders are the most common work-related health problems. The risk of musculoskeletal disorders is increased by working in a cold environment. The present study aims to investigate the effects of working years on the body. Methods: We examined the effects of the working years on the musculoskeletal system and carpal tunnel syndrome symptoms of the individuals who were engaged in cutting, shredding, packaging, bagging and transportation operations at 9 degrees and lower ambient temperatures in a poultry factory in Turkey. Nordic Musculoskeletal Questionnaire (NMQ) was used to evaluate musculoskeletal symptoms of the individuals. Boston Carpal Tunnel Syndrome Questionnaire (BCTQ) was used to investigate the carpal tunnel symptoms. Individuals grouped according to their total working years in a cold factory setting. Groups were formed as less than two years, between two and five years, between six and nine years, and ten years or more.

Results: This study showed that the increase in working years in a cold factory setting might lead to a feeling of pain and discomfort in various regions of the body, disrupt ordinary works due to the pain felt $(p<0.05)$. This study also showed that the severity of the symptoms felt because carpal tunnel syndrome worsened, especially when an individual has been working for more than ten years in cold.
\end{abstract}

Conclusion: Working in the cold for a long time may result in long-term health effects on the human body.

Keywords: Cold temperature; cumulative trauma disorders; discomfort; pain; poultry sector.

\section{Özet}

Amaç: Iş̧le ilgili sağlık sorunları arasında en yaygın olanı kas-iskelet sistemi hastalıklarıdır. Soğuk bir ortamda çalışmak kasiskelet sistemi rahatsızlıkları riskini arttırmaktadır. Bu çalışmanın amacı, soğuk ortamda çalışma yıllarının vücut üzerindeki etkilerini araştırmaktı.

Gereç ve Yöntem: Çalışma yıllarının Türkiye'deki bir fabrikada 9 derece ve altında kanatlı hayvanlarda kesme, parçalama, paketleme, torbalama ve taşıma işlemleri yapan ve düşük ortam sıcaklıklarında çalışan bireylerin kas-iskelet sistemi ve karpal tünel sendromu semptomları üzerindeki etkisini inceledik. Bireylerin kas iskelet sistemi semptomlarını değerlendirmek için İskandinav Kas İskelet Sistemi Sorgusu kullanıldı. Karpal tünel semptomlarını araştırmak için Boston Karpal Tünel Sendromu Anketi kullanıldı. Bireyler toplam çalışma yıllarına göre gruplandııımışlardır. Gruplar iki yıldan az, iki ila beş yıl, altı ila dokuz yıl ve on yıl veya daha fazla olarak kuruldu.

Bulgular: Bu çalışma soğuk bir fabrika ortamında çalışma yıllarındaki artışın, vücudun çeşitli bölgelerinde ağrı ve rahatsızlık hissinde artışa yol açabileceğini, hissedilen ağrı nedeniyle sıradan işlerin etkilenebileceğini göstermiştir $(p<0,05)$. Ayrıca bu çalışma, karpal tünel sendromu nedeniyle hissedilen semptomların ciddiyetinin, özellikle on yıldan fazla bir süre soğukta çalışıldığında kötüleştiğini göstermiştir.

Sonuç: Uzun süre soğukta çalışmak, insan vücudunda sağlık problemlerine neden olmaktadır.

Anahtar sözcükler: Soğuk; kümülatif travma bozuklukları; rahatsızık; ağrı; kanatlı hayvan sektörü.

\section{Introduction}

Musculoskeletal disorders are the most common work-related health problems. Generally, manual work, heavy physical work, working in inappropriate and static postures, continuous repetition of movements and vibration are the main factors that cause these disorders. Occupational disabilities and disorders are an important issue in developing countries,

\section{Department of Physical Therapy and Rehabilitation, Bolu Abant İzzet Baysal University, Bolu, Turkey}

Submitted (Başvuru tarihi) 17.06.2019 Accepted after revision (Düzeltme sonrası kabul tarihi) 29.01.2020 Available online date (Online yayımlanma tarihi) 05.05.2020

Correspondence: Dr. Yasin Devran Altuntaş. Bolu Abant İzzet Baysal Üniversitesi, Kemal Demir Fizik Tedavi ve Rehabilitasyon Yüksekokulu, Gölköy Kampüsü, 14030 Bolu, Turkey.

Phone: +90 - 506 - 8218956 e-mail:ydaltuntas@gmail.com

(C) 2020 Turkish Society of Algology 
which account for $70 \%$ of the global workforce. Recent evaluations show that job-related health loss causes significant losses in total national production percentages. ${ }^{[1]}$

Most of the musculoskeletal disorders associated with work are cumulative, occurring in the long term by repeating low or high-intensity loads. Symptoms vary from discomfort and pain to reduced body function and disability. The extent to which these diseases originate from work life is not clear, but the effects on daily life are shown..$^{[2]}$ It can also interfere with activities that need to be done at work, reduce production, cause workers to obtain sick leave and increase chronic occupational insufficiency. ${ }^{[3]}$

Carpal tunnel syndrome (CTS) is a neuromuscular condition caused by compression neuropathy and constitutes $90 \%$ of all nerve compressions. ${ }^{[4]}$ Commonly reported CTS symptoms include wrist and hand pain, paresthesia, muscle weakness and loss of dexterity. ${ }^{[5] 7]}$ Female gender, increased age, physical illness, repetitive hand use, and occupation are potential risk factors for CTS development. ${ }^{[4,7]}$

In many cross-sectional studies, low environmental temperature and routine work have been shown to increase the risk of musculoskeletal disorders. ${ }^{[8-10]}$ It is accepted that the risk of CTS is high in professions where meat and fish were processed. ${ }^{[8,11,12]}$

Although the cold has been shown to adversely affect various parameters of muscle performance, such as strength, speed, and coordination, few studies have investigated the effects of cold on body functions. ${ }^{[13]}$ This study aimed to investigate the effects of working years on the musculoskeletal system and especially on carpal tunnel syndrome symptoms.

\section{Material and Methods}

This study included 568 individuals who were engaged in cutting, shredding, packaging, bagging and transportation operations at 9 degrees and lower ambient temperatures in a poultry factory. Evaluations were made at the factory where the individuals worked. After the assessment forms were distributed to the workers, necessary explanations were made about the participation and questionnaires. Inclusion criteria were to work in a cold environment at least 9 degrees Celsius in the factory, to be able to understand and respond to survey, to be between the ages of $18-60$, and to be a volunteer. The exclusion criteria were to be diagnosed with rheumatic disease, to have undergone surgery due to an orthopedic disorder, to have a history of trauma that still affects the person physically, and to receive treatment due to a discomfort requiring physical therapy. This descriptive study approved by Abant Izzet Baysal University Clinical Research and Ethics Committee, (Decision No. 121 on 26/05/2017. Resolution NO: 2017/37).

765 people were tested for convenience. 178 people were excluded from the study because they did not work in cold conditions and had a history of orthopedic surgery and 9 people refused to participate. During the study, 568 individuals were included in the evaluation criteria. Of those working in cold conditions, 506 were working at 5 degrees and below, and 62 at 9 degrees. Ambient temperature was measured by the factory measuring system. The individuals included in the study were informed about the study and their consent was obtained. Individuals grouped as less than 2 years ( $n=211), 2-4$ years $(n=140), 5-9$ years ( $n=147)$ and 10 years or more $(n=70)$ according to working years in cold.

\section{Nordic Musculoskeletal Questionnaire}

Symptoms of the musculoskeletal system were evaluated using the Nordic Musculoskeletal Questionnaire (NMQ) developed in 1987. ${ }^{[14]}$ Kahraman et al. ${ }^{[15]}$ adapted the NMQ to the Turkish language in 2016. The questionnaire has two parts. In the first part; name, surname, date of evaluation, gender, date of birth, how many years and months the current work was done, the average number of hours worked in a week, the weight, height and the dominant side were questioned. The second part is supported by a body map image to indicate that nine symptoms (neck, shoulder, back, elbow, waist circumference, wrist/hand, hip/thighs, knees and ankles/feet) are present. The participant can see the approximate positions of the body parts mentioned in the body diagramme of the questionnaire. The question of whether there are any problems (pain, discomfort) in the aforementioned 9 regions, whether or not a normal job (at home or outside the home) is caused by pain, and whether there is any pain during the last 7 days or not, is one of the questions in the format of yes/no in the questionnaire format. ${ }^{[15]}$ 
Table 1. Distribution of gender, dominant extremity and smoking status of working year groups

\begin{tabular}{|c|c|c|c|c|c|c|c|}
\hline & $\begin{array}{l}\text { Less than } 2 \text { years } \\
\qquad \begin{array}{c}(n=211) \\
n\end{array}\end{array}$ & $\begin{array}{c}2-5 \text { years } \\
(n=140) \\
n\end{array}$ & $\begin{array}{c}5-10 \text { years } \\
(n=147) \\
n\end{array}$ & $\begin{array}{c}\text { Over } 10 \text { years } \\
(n=70) \\
n\end{array}$ & Total & $x^{2}$ & $\mathbf{p}$ \\
\hline \multicolumn{8}{|l|}{ Sex } \\
\hline Female & 123 & 77 & 89 & 33 & 319 & \multirow{2}{*}{1.112} & \multirow{2}{*}{0.376} \\
\hline Male & 88 & 63 & 61 & 37 & 249 & & \\
\hline \multicolumn{8}{|c|}{ Dominant extremity } \\
\hline Right & 192 & 129 & 129 & 62 & 512 & \multirow{2}{*}{1.940} & \multirow{2}{*}{0.585} \\
\hline Left & 19 & 11 & 18 & 8 & 56 & & \\
\hline \multicolumn{8}{|c|}{ Smoking status } \\
\hline Yes & 88 & 56 & 52 & 28 & 224 & \multirow{2}{*}{1.499} & \multirow{2}{*}{0.683} \\
\hline No & 123 & 84 & 95 & 42 & 344 & & \\
\hline
\end{tabular}

$x^{2}$ : Chi-square test; $n$ : Number of individuals; $p>0.05$.

\section{Boston Carpal Tunnel Syndrome Questionnaire} Symptoms of Carpal Tunnel Syndrome were evaluated using the Boston Carpal Tunnel Syndrome Questionnaire (BCTQ). The BCTQ developed by Levine et al. ${ }^{[16]}$ in 1993, later adapted to Turkish by Sezgin et al. ${ }^{[17]}$ in 2006. BCTQ consists of two parts. The first part is called the Symptom Severity Scale (SSS). It has 11 questions. Questions the symptoms related to carpal tunnel syndrome. The second part, the Functional State Scale (FSS), reveals the level of difficulty experienced in the 8 activities designed. Scoring is generally calculated in 1-5 for each question and the increase in score indicates worsening of symptoms. ${ }^{[17]}$

\section{Demographic Questionnaire}

The questionnaire examined gender, date of birth, daily working hours in cold, working days in a week, body weight, length, dominant extremity, presence of chronic disease, use of painkillers, the level of pain felt while resting and working.

\section{Statistical Analysis}

The minimum number of individuals required for each group found as 67 by using the $G^{*}$ Power program with the settings of $a<0.05 \beta=\% 80$ power. Descriptive statistical methods used for demographic information. The chi-square test was used to compare NMQ scores to the work years. Since there was an equal distribution in the evaluation, the Anova test was used for comparing the groups' BCTQ scores. For the post-hoc analysis, the Bonferroni test was used. The statistical significance level of the data taken as $p<0.05$. SPSS 22 program was used for the analysis.

\section{Results}

Distribution of gender, dominant extremity and smoking status of working year groups

The mean age of the patients was $36,92 \pm 8,61$ years, the mean weight was $71,47 \pm 13,10 \mathrm{~kg}$, the mean height was $165,35 \pm 8,83 \mathrm{~cm}$, body mass index was $26,12 \pm 4,23 \mathrm{~kg} / \mathrm{m}^{2}$.

$319(56.1 \%)$ of the participants were female and 249 $(43.9 \%)$ were male. $512(90.3 \%)$ of the individuals were right-handed and 56 (9.7\%) were left-handed. There was a normal distribution in the gender, dominant extremity and smoking between groups (Table 1) ( $p>0.05)$.

\section{Comparison between NMQ scores of working years groups}

The effect of the cold working years on the scores of the NMQ was investigated. Answers for "Have you at any time during the last twelve months had trouble (such as ache, pain, discomfort, numbness)?"shown a significant difference between groups for hip and knee regions. Answers for"Have you at any time during the last twelve months been prevented from doing your daily activities (at home or away from home) because of the trouble?" shown significant difference between groups for hip and elbow regions. Answers for "Have you had trouble at any time during the last seven days?" question shown significant difference shoulder region $(p<0.05)$. No significant change was observed for all three questions in other regions ( $p>0.05$ ) (Tables 2, 3). 
Table 2. Comparison between NMQ scores and working years of the neck and upper extremities

\begin{tabular}{|c|c|c|c|c|c|c|}
\hline & $\begin{array}{l}\text { Less than } 2 \text { years } \\
\qquad \begin{array}{c}(n=211) \\
n\end{array}\end{array}$ & $\begin{array}{c}2-5 \text { years } \\
(n=140) \\
n\end{array}$ & $\begin{array}{c}5-10 \text { years } \\
(n=147) \\
n\end{array}$ & $\begin{array}{l}\text { Over } 10 \text { years } \\
\qquad \begin{array}{c}(n=70) \\
n\end{array}\end{array}$ & $x^{2}$ & $\mathbf{p}$ \\
\hline \multicolumn{7}{|l|}{ Neck A } \\
\hline Yes & 140 & 88 & 94 & 38 & \multirow{2}{*}{3.333} & \multirow{2}{*}{0.343} \\
\hline No & 71 & 52 & 53 & 32 & & \\
\hline \multicolumn{7}{|l|}{ Neck B } \\
\hline Yes & 186 & 124 & 123 & 54 & \multirow{2}{*}{6.667} & \multirow{2}{*}{0.083} \\
\hline No & 25 & 16 & 24 & 16 & & \\
\hline \multicolumn{7}{|l|}{ Neck C } \\
\hline Yes & 149 & 101 & 106 & 42 & \multirow{2}{*}{3.993} & \multirow{2}{*}{0.262} \\
\hline No & 62 & 39 & 41 & 20 & & \\
\hline \multicolumn{7}{|c|}{ Shoulders A } \\
\hline Yes & 130 & 79 & 86 & 38 & \multirow{2}{*}{1.599} & \multirow{2}{*}{0.660} \\
\hline No & 81 & 61 & 61 & 32 & & \\
\hline \multicolumn{7}{|c|}{ Shoulders B } \\
\hline Yes & 182 & 124 & 129 & 55 & \multirow{2}{*}{4.402} & \multirow{2}{*}{0.221} \\
\hline No & 29 & 16 & 18 & 15 & & \\
\hline \multicolumn{7}{|c|}{ Shoulders C } \\
\hline Yes & 148 & 98 & 114 & 40 & \multirow{2}{*}{9.533} & \multirow{2}{*}{0.023} \\
\hline No & 63 & 42 & 33 & 30 & & \\
\hline \multicolumn{7}{|c|}{ Elbows A } \\
\hline Yes & 181 & 114 & 121 & 54 & \multirow{2}{*}{3.091} & \multirow{2}{*}{0.378} \\
\hline No & 30 & 26 & 26 & 16 & & \\
\hline \multicolumn{7}{|c|}{ Elbows B } \\
\hline Yes & 197 & 135 & 140 & 60 & \multirow{2}{*}{9.900} & \multirow{2}{*}{0.019} \\
\hline No & 14 & 5 & 7 & 10 & & \\
\hline \multicolumn{7}{|c|}{ Elbows C } \\
\hline Yes & 184 & 128 & 128 & 56 & \multirow{2}{*}{5.534} & \multirow{2}{*}{0.137} \\
\hline No & 27 & 12 & 19 & 14 & & \\
\hline Wrists/h & & & & & & \\
\hline Yes & 111 & 71 & 80 & 27 & & \\
\hline No & 100 & 69 & 67 & 43 & 3.234 & 0.115 \\
\hline Wrists/h & & & & & & \\
\hline Yes & 170 & 120 & 122 & 52 & 4426 & 0219 \\
\hline No & 41 & 20 & 25 & 18 & T. & 0.213 \\
\hline Wrists/h & & & & & & \\
\hline Yes & 134 & 104 & 105 & 45 & 5742 & 0.125 \\
\hline No & 77 & 36 & 42 & 25 & 2. & \\
\hline
\end{tabular}

$X^{2}$ : Chi-square test; A: Have you at any time during the last 12 months had trouble (ache, pain, discomfort)?; B: Have you at any time during the last 12 months been prevented from doing your normal work (at home or away from home) because of the trouble?; C: Have you had trouble at any time during the last 7 days? $p<0.05$.

Comparison between the BCTQ scores of working years groups

The effect of individuals' working years on the results of Boston carpal tunnel syndrome was examined. There was no statistical difference between the work year groups in the Boston FSS score $(p=0.577)$, but it was found that Boston SSS ( $p=0.008$ ) scores get higher as individual's working years increase $(p<0.05)$ (Table 4$)$. 
Table 3. Comparison between NMQ scores and working years of the spine and lower extremities

\begin{tabular}{|c|c|c|c|c|c|c|}
\hline & $\begin{array}{l}\text { Less than } 2 \text { years } \\
\qquad \begin{array}{c}(n=211) \\
n\end{array}\end{array}$ & $\begin{array}{c}2-5 \text { years } \\
(n=140) \\
n\end{array}$ & $\begin{array}{c}\text { 5-10 years } \\
(n=147) \\
n\end{array}$ & $\begin{array}{c}\text { Over } 10 \text { years } \\
(n=70) \\
n\end{array}$ & $x^{2}$ & $\mathbf{p}$ \\
\hline \multicolumn{7}{|c|}{ Upper back A } \\
\hline Yes & 134 & 76 & 89 & 38 & \multirow{2}{*}{3.830} & \multirow{2}{*}{0.280} \\
\hline No & 77 & 64 & 58 & 32 & & \\
\hline \multicolumn{7}{|c|}{ Upper back B } \\
\hline Yes & 183 & 121 & 128 & 54 & \multirow{2}{*}{4.607} & \multirow{2}{*}{0.203} \\
\hline No & 28 & 19 & 19 & 16 & & \\
\hline \multicolumn{7}{|c|}{ Upper back C } \\
\hline Yes & 141 & 104 & 112 & 47 & \multirow{2}{*}{4.958} & \multirow{2}{*}{0.175} \\
\hline No & 70 & 36 & 35 & 23 & & \\
\hline \multicolumn{7}{|c|}{ Low back A } \\
\hline Yes & 115 & 62 & 75 & 29 & \multirow{2}{*}{5.595} & \multirow{2}{*}{0.133} \\
\hline No & 96 & 78 & 72 & 41 & & \\
\hline \multicolumn{7}{|c|}{ Low back B } \\
\hline Yes & 174 & 111 & 121 & 51 & \multirow{2}{*}{3.556} & \multirow{2}{*}{0.314} \\
\hline No & 37 & 29 & 26 & 19 & & \\
\hline \multicolumn{7}{|c|}{ Low back C } \\
\hline Yes & 136 & 98 & 105 & 41 & \multirow{2}{*}{4.224} & \multirow{2}{*}{0.238} \\
\hline No & 72 & 42 & 42 & 29 & & \\
\hline \multicolumn{7}{|c|}{ Hips/tights A } \\
\hline Yes & 191 & 122 & 120 & 53 & \multirow{2}{*}{11.817} & \multirow{2}{*}{0.008} \\
\hline No & 20 & 18 & 27 & 17 & & \\
\hline \multicolumn{7}{|c|}{ Hips/tights B } \\
\hline Yes & 202 & 133 & 137 & 58 & \multirow{2}{*}{14.882} & \\
\hline No & 9 & 7 & 10 & 12 & & 0.002 \\
\hline Hips/tig & & & & & & \\
\hline Yes & 190 & 127 & 135 & 57 & & \\
\hline No & 21 & 13 & 12 & 13 & 6.043 & 0.110 \\
\hline Knees A & & & & & & \\
\hline Yes & 154 & 96 & 90 & 34 & & \\
\hline No & 57 & 44 & 57 & 36 & 15.629 & 0.001 \\
\hline Knees B & & & & & & \\
\hline Yes & 192 & 123 & 129 & 56 & & \\
\hline No & 19 & 17 & 18 & 14 & 6.058 & 0.109 \\
\hline Knees C & & & & & & \\
\hline Yes & 167 & 111 & 115 & 49 & & \\
\hline No & 44 & 29 & 32 & 21 & 2.884 & 0.410 \\
\hline Ankles/ & & & & & & \\
\hline Yes & 119 & 85 & 82 & 31 & & \\
\hline No & 92 & 55 & 65 & 39 & 5.165 & 0.160 \\
\hline Ankles/ & & & & & & \\
\hline Yes & 176 & 124 & 119 & 53 & & \\
\hline No & 35 & 16 & 28 & 17 & 6.200 & 0.102 \\
\hline Ankles/ & & & & & & \\
\hline Yes & 144 & 101 & 104 & 42 & & 0315 \\
\hline No & 67 & 39 & 43 & 28 & 3.540 & 0.315 \\
\hline
\end{tabular}

$\mathrm{X}^{2}$ : Chi-square test; A: Have you at any time during the last 12 months had trouble (ache, pain, discomfort)?; B: Have you at any time during the last 12 months been prevented from doing your normal work (at home or away from home) because of the trouble?; C: Have you had trouble at any time during the last 7 days? $\mathrm{p}<0.05$. 
Table 4. Comparison between the BCTQ scores (functional status scale and symptoms severity scale) of working years groups

\begin{tabular}{|c|c|c|c|c|c|c|c|}
\hline & $\begin{array}{l}\text { Less than } 2 \text { years } \\
\qquad \begin{array}{c}(\mathbf{n}=\mathbf{2 1 1}) \\
\mathrm{X} \pm \mathrm{SD}\end{array}\end{array}$ & $\begin{array}{c}2-5 \text { years } \\
(n=140) \\
X \pm S D\end{array}$ & $\begin{array}{c}5-10 \text { years } \\
(n=147)\end{array}$ & $\begin{array}{l}\text { Over } 10 \text { years } \\
\quad(n=70)\end{array}$ & $f$ & df & $\mathbf{p}$ \\
\hline Boston FSS & $1.30 \pm 0.62$ & $1.38 \pm 0.81$ & $1.39 \pm 0.75$ & $1.41 \pm 0.78$ & 0.660 & 564 & 0.577 \\
\hline Boston SSS & $1.74 \pm 0.80$ & $1.70 \pm 0.89$ & $1.74 \pm 0.74$ & $2.11 \pm 1.18$ & 3.968 & 564 & 0.008 \\
\hline
\end{tabular}

f: One way anova; df: Degree of freedom; $\mathrm{X}$ : Average value; SD: Standard deviation; FSS: Functional state scale; $\mathrm{p}<0.05$.

Table 5. Post-hoc evaluations of Boston SSS scores for working year groups

\begin{tabular}{cccccc}
\hline Working years & Working years & Mean & & SD & p \\
\hline & Less than 2 & 2-5 years & 0.04127 & 0.09469 & 1.000 \\
& & 5-10 years & 0.00048 & 0.09332 & 1.000 \\
Boston SSS & Over 10 years & -0.36718 & 0.11982 & $\mathbf{0 . 0 1 4}$ \\
& 2-5 years & Less than 2 & -0.04127 & 0.09469 & 1.000 \\
& & 5-10 years & -0.04079 & 0.10258 & 1.000 \\
& & Over 10 years & -0.40844 & 0.12716 & $\mathbf{0 . 0 0 8}$ \\
& & Less than 2 & -0.00048 & 0.09332 & 1.000 \\
& & 2-5 years & 0.04079 & 0.10258 & 1.000 \\
& & Over 10 years & -0.36766 & 0.12615 & $\mathbf{0 . 0 2 2}$ \\
& Over 10 years & Less than 2 & 0.36718 & 0.11982 & $\mathbf{0 . 0 1 4}$ \\
& 2-5 years & 0.40844 & 0.12716 & $\mathbf{0 . 0 0 8}$ \\
& & 5-10 years & 0.36766 & 0.12615 & $\mathbf{0 . 0 2 2}$ \\
\hline
\end{tabular}

F: One way anova post hoc Bonferoni; SD: Standard deviation; $\mathrm{p}<0.05$.

Post-hoc evaluations of Boston SSS scores

Post-hoc evaluations of the Boston SSS scores according to their working years are the work year was more than ten years, there was a statistically significant difference in scores compared to all other groups $(p<0.05)$ (Table 5).

\section{Discussion}

Exposure to cold in the work environment may be due to cold weather/wind exposure, dipping into water or touching cold surfaces. According to standard guidelines and norms, cold work can be defined as a situation of cold or cold feeling in a working environment. Even in a light physical job with an ambient temperature below 10 degrees can create this sensation. According to other international standards, cold work is generally defined for jobs with an ambient temperature below 10-15 degrees. ${ }^{[18]}$

It is found that the pain felt on the shoulder in the last 7 days was related to the working years. Shoulder is a joint where the problems are common in the works where active use of the upper extremity is required. In cold conditions, these muscles cannot work properly, causing muscular pain and injury. Decrease in muscle temperature adversely affects all parameters such as endurance, power, speed, and coordination of muscle performance. ${ }^{[19]}$

The decrease in the performance of hypothermic skeletal muscle can also be attributed to a decrease in nerve conduction velocity. ${ }^{[20,21]}$ Muscle function and co-ordination also deteriorate due to the suppression of agonist muscle activity and increased antagonist muscle activity in hypothermic muscle. ${ }^{[21,22]}$ Fatigue occurs earlier with these changes and repetitive activities when muscle temperature falls. ${ }^{[21,23]}$ These effects prepare the ground for overuse injuries. ${ }^{[2]}$

When muscle temperature drops, muscle spindle activity, and motor neuron activity decrease, therefore muscle tension reflex decreases. This prevents the muscle from releasing sufficient force. ${ }^{[13]}$ It is re- 
ported that the working year and the working hours were effective on shoulder problems in cashiers. ${ }^{[25]}$

In this study, the increase in the working year and the disruption of the ordinary works due to pain felt in the elbow in the last 12 mounts were found to be correlated. The elbow is an active joint in meat processing and packaging activities. Therefore it is susceptible to injuries and disabilities.

The incidence of epicondylitis was reported to be $11.3 \%$ in female sausage makers, $7 \%$ in female packers and $6.4 \%$ in male meat cutters. The temperature of the environment where the sausages are working is 20 degrees and the temperature of the women working in the package is $8-10$ degrees. The incidence of these diseases is reported to be less than $1 \%$ in non-demanding workers. ${ }^{[8]}$

In this study, the problems experienced in the knee and hip in the last 12 months (pain, discomfort) and the disruption of the ordinary works due to the pain felt in the hip in the last 12 months were found to be related. In our opinion, there are 2 possible causes of pain in the hips and knees. The first is the effect of low ambient temperature on muscle performance. Secondly, it can be defined as muscular pain due to long term standing. It is reported that individuals exposed to severe cold ( $-10,-25$ degrees) have been reported to have more musculoskeletal pain than those exposed to moderate cold $(-5,5$ degrees) and MDs developed in individuals as a result of cumulative exposure to cold work environment and waist and knee symptoms were very common in individuals exposed to cold for 5 years or more. ${ }^{[26]}$

It has been proven that long term repetitive hand and wrist movements, uncomfortable hand placement and position, continuous pressure on wrist or hand are related to Carpal Tunnel Syndrome and complaints about Carpal Tunnel Syndrome are seen more frequently in people who carry out activities involving such risks. ${ }^{[27,28]}$ Participants were exposed to several of these factors at the same time. These factors can be counted as cold, continuous and long term hand-wrist activities and continuous pressure due to cutting action. We think that the continuous work of our participants increased the risk of microtraumas. Moreover, the slowing of the nerve conduction speed and the decrease of muscle performance due to cold are also effective factors. ${ }^{[20,21]}$
Our study has four main limitations. Firstly, employees could not be grouped according to their professions because there were many different jobs in the factory setting. Secondly, jobs were not normally distributed for gender groups. Women were mostly employed in cutting and packaging, where more men working in storage areas. Thirdly, tests used to diagnose carpal tunnel syndrome could not be used due to work intensity and lack of time. Fourthly, the absence of a control group of individuals who did not work in a cold environment made a possibly meaningful comparison impossible. Therefore, increased musculoskeletal problems may be due to the cold environment or increased years of work. Considering the shortcomings of this study, some suggestions can be given for further studies. The physical difficulty of the work performed and the postures taken to do the work can be properly classified. Nerve conduction tests for carpal tunnel syndrome can be included in the study. Working in populations where genders can normally be distributed can lead to more objective results.

\section{Conclusions}

The results of this study demonstrated that the increase in working years in a cold factory setting may lead to a feeling of pain and discomfort in various regions of the body, disrupt ordinary works due to the pain felt and worsen the symptoms for carpal tunnel syndrome. There was a correlation between the increased working year and the pain felt on the shoulder in the last 7 days was found. There was a correlation between the increasing work years and the disruption of the ordinary works due to the pain felt in the elbow and the hip. The problems (pain, discomfort) felt on the knees and hips in the last 12 months were related to the increasing work years. It was concluded that the increase in working years worsened the symptoms of carpal tunnel syndrome. Participants exhibited a worse picture both functionally and symptomatically.

Ethics Committee Approval: This descriptive study approved by Abant Izzet Baysal University Clinical Research and Ethics Committee, (Decision No. 121 on 26/05/2017. Resolution NO: 2017/37).

Conflict-of-interest issues regarding the authorship or article: None declared.

Peer-rewiew: Externally peer-reviewed. 


\section{References}

1. Girish N, Ramachandra K, Arun G M, Asha K. Prevalence of musculoskeletal disorders among cashew factory workers. Arch Environ Occup Health 2012;67(1):37-42. [CrossRef]

2. Escorpizo R. Understanding work productivity and its application to work-related musculoskeletal disorders. Int J Ind Ergon 2008;38(3):291-7. [CrossRef]

3. Kivimäki $M$, Leino-Arjas $P$, Kaila-Kangas $L$, Luukkonen $R$, Vahtera J, Elovainio $M$, et al. Is incomplete recovery from work a risk marker of cardiovascular death? Prospective evidence from industrial employees. Psychosom Med 2006;68(3):402-7. [CrossRef]

4. Aroori S, Spence RA. Carpal tunnel syndrome. Ulster Med J 2008;77(1):6-17.

5. Rempel D, Evanoff B, Amadio PC, de Krom M, Franklin G, Franzblau $A$, et al. Consensus criteria for the classification of carpal tunnel syndrome in epidemiologic studies. Am J Public Health 1998;88(10):1447-51. [CrossRef]

6. Viera AJ. Management of carpal tunnel syndrome. Am Fam Physician 2003;68(2):265-72. [CrossRef]

7. Atroshi I, Gummesson C, Johnsson R, Ornstein E, Ranstam J, Rosén I. Prevalence of carpal tunnel syndrome in a general population. JAMA 1999;282(2):153-8. [CrossRef]

8. Kurppa K, Viikari-Juntura E, Kuosma E, Huuskonen M, Kivi $P$. Incidence of tenosynovitis or peritendinitis and epicondylitis in a meat-processing factory. Scand J Work Environ Health 1991;17(1):32-7. [CrossRef]

9. Piedrahita H, Punnett L, Shahnavaz H. Musculoskeletal symptoms in cold exposed and non-cold exposed workers. Int J Ind Ergon 2004;34:271-8. [CrossRef]

10. Sormunen E, Oksa J, Pienimäki T, Rissanen S, Rintemaki H. Muscular and cold strain of female workers in meatpacking work. Int J Ind Ergon 2006;36:713-20. [CrossRef]

11. Chiang HC, Chen SS, Yu HS, Ko YC. The occurrence of carpal tunnel syndrome in frozen food factory employees. Gaoxiong Yi Xue Ke Xue Za Zhi 1990;6(2):73-80.

12. Kim JY, Kim Jl, Son JE, Yun SK. Prevalence of carpal tunnel syndrome in meat and fish processing plants. J Occup Health 2004;46(3):230-4. [CrossRef]

13. Oksa J. Neuromuscular performance limitations in cold. Int J Circumpolar Health 2002;61(2):154-62. [CrossRef]

14. Kuorinka I, Jonsson B, Kilbom A, Vinterberg $H$, Biering-Sørensen $F$, Andersson $G$, et al. Standardised Nordic questionnaires for the analysis of musculoskeletal symptoms. Appl Ergon 1987;18(3):233-7. [CrossRef]

15. Kahraman T, Genç A, Göz E. The Nordic Musculoskel- etal Questionnaire: cross-cultural adaptation into Turkish assessing its psychometric properties. Disabil Rehabil 2016;38(21):2153-60. [CrossRef]

16. Levine DW, Simmons BP, Koris MJ, Daltroy LH, Hohl GG, Fossel $\mathrm{AH}$, et al. A self-administered questionnaire for the assessment of severity of symptoms and functional status in carpal tunnel syndrome. J Bone Joint Surg Am 1993;75(11):1585-92. [CrossRef]

17. Sezgin $M$, Incel NA, Serhan S, Camdeviren $H$, As I, Erdoğan C. Assessment of symptom severity and functional status in patients with carpal tunnel syndrome: reliability and functionality of the Turkish version of the Boston Questionnaire. Disabil Rehabil 2006;28(20):1281-5. [CrossRef]

18. Mäkinen TM, Hassi J. Health problems in cold work. Ind Health 2009;47(3):207-20. [CrossRef]

19. Racinais S, Oksa J. Temperature and neuromuscular function. Scand J Med Sci Sports 2010;20:1 -18. [CrossRef]

20. De Jong RH, Hershey WN, Wagman IH. Nerve conduction velocity during hypothermia in man. Anesthesiology 1966;27(6):805-10. [CrossRef]

21. Wakabayashi H, Oksa J, Tipton, MJ. Exercise performance in acute and chronic cold exposure. J Sports Med Phys Fitness 2015;4:177-85. [CrossRef]

22. Oksa J, Rintamäki H, Rissanen S. Muscle performance and electromyogram activity of the lower leg muscles with different levels of cold exposure. Eur J Appl Physiol Occup Physiol 1997;75(6):484-90. [CrossRef]

23. Clarke RS, Hellon RF, Lind AR. The duration of sustained contractions of the human forearm at different muscle temperatures. J Physiol 1958;143(3):454-73. [CrossRef]

24. Oksa J, Paasovaara S, Ollila T. Intermittently increased repetitive work intensity and neuromuscular function in the cold. Ind Health 2012;50(4):307-15. [CrossRef]

25. Niedhammer I, Landre MF, LeClerc A, Bourgeois F, Franchi $\mathrm{P}$, Chastang JF, et al. Shoulder disorders related to work organization and other occupational factors among supermarket cashiers. Int J Occup Environ Health 1998;4(3):16878. [CrossRef]

26. Chen F, Li T, Huang $\mathrm{H}$, Holmér I. A field study of cold effects among cold store workers in China. Arctic Med Res 1991;50:99-103.

27. Silverstein BA, Fine LJ, Armstrong TJ. Occupational factors and carpal tunnel syndrome. Am J Ind Med 1987;11(3):34358. [CrossRef]

28. Geoghegan JM, Clark DI, Bainbridge LC, Smith C, Hubbard R. Risk factors in carpal tunnel syndrome. J Hand Surg Br 2004;29(4):315-20. [CrossRef] 